\title{
Linguistic Characteristic of Narrative Text Written by Male and Female Students
}

\author{
Nurul Hasanah \\ English Applied Linguistic Study \\ Program \\ Postgraduate School, UNIMED \\ Medan, Indonesia \\ nurul.ana0307@gmail.com
}

\author{
Zainuddin \\ English Applied Linguistic Study \\ Program \\ Postgraduate School, UNIMED \\ Medan, Indonesia \\ zainuddin52@yahoo.com
}

\author{
Dr. Anni Holila Pulungan, \\ M.Hum \\ English Applied Linguistic Study \\ Program \\ Postgraduate School, UNIMED \\ Medan, Indonesia \\ anniholilapulungan@gmail.com
}

\begin{abstract}
Language is a reflection of speakers. A person can guess the identity such as the origin, character, or behavior of the interlocutor of the language he uses. Gender affect the use of language, both oral and written language. As Lakoff said that male and female groups have different linguistic characteristics. As an essential skill in learning English, writing involves the application of grammar and sentence pattern, vocabulary, or diction and cross cultural understanding. It can be said that writing ability is someone capability to express their idea in the form of written representasion. Narrative is a fundamental language process for learning how to give an opinion of a story, write about a story and imagine thinking of student. By writing narrative text, they know how to express their opinion. The question is do male and female students also use language differently in writing. In line with this idea, the objective of this study is to investigate the linguistic form of narrative text written by male and female students proposed by Lakoff 1975, such as, empty adjectives, hedge, intensifier, hypercorrect grammar super polite form, tag question and emphatic stress, even though the characteristics of color words and question intonation have not been found in the characters utterances. The data of this study will be gathered by sentences in narrative text written male and female students in Senior High School to write a topic given about their experience
\end{abstract}

Keywords - linguistic characteristics, gender, writing, narrative

\section{INTRODUCTION}

Language as a means of communication is a central fact of human existence and social process. Everyone who is born indirectly has their own language. Even if someone grows up in the same environment they still have different languages because the differences their experience. On the other hand, language is a reflection of speakers. Likewise with men and women who are two different gender, it also influences the language.

Some researchers show that man and woman use language differently when speaking either the same or different sex. Gender differentiation make a different characteristic between male and female in language. Like Janet Holmes stated 'The linguistic forms used by women and men contrast - to different degrees - in all speech communities'. Men and women have their own language characters. Language is a reflection of speakers. A person can guess the identity such as the origin, character, or behavior of the interlocutor of the language he uses. Gender affect the use of language, both oral and written language.

As Lakoff said that male and female groups have different linguistic characteristics. As an essential skill in learning English, writing involves the application of grammar and sentence pattern, vocabulary, or diction and cross cultural understanding. It can be said that writing ability is someone capability to express their idea in the form of written representasion.

By writing narrative text, they know how to express their opinion. The question is do male and female students also use language differently in writing. In line with this idea, the objective of this study is to investigate the linguistic form of narrative text written by male and female students

\section{THEORETICAL REVIEW}

Tannen (1990) in Scollon and Scollon (1995: 9) states that different men and women are already innate or natural. Some references indicate that there are differences between male and female languages. Coulmas (2005: 36-37) states that men and women choose different vocabulary because naturally they are different.

Gender and language are disciplines that are relatively rare in modern linguistics. It revealed the characteristics of differences in language use between women and men (Gray, 2001: 19). The difference approach (Coates 1986; Tannen 1990) believes that men and women belong to differences subcultures and that any linguistic differences can be attributed to cultural differences. The sociological characters of male and female are represented in their linguistics characteristics of the communication they do.

Wardhaugh (1988) examines that there are language differences between men and women. The difference includes several linguistic levels with some examples of cases found in the language:

(a) Phonological differences. Found phonological differences between male and female language speeches. 
(b) Differences at the level of morphology and lexicon. In this level Wardhaugh take the example from Lakoff who states that in English women often use color vocabulary such as mauve, beige, aquamarine, lavender, and magenta; while men don't.

As Kanaris (1999) stated the differences between male and female in writing that boys tend to use $I$ and girls tend to use We as indicative of boys' positioning themselves as the agents in their own narrative, while girls position themselves ass participant and observes. She describe male writers as "eventoriented" and egocentric, while girls are pretended as more skilled both as word and text level.

According to Crawford (1997), as follows: Male in communication always want to show their characteristics of power, as follow:

\section{Direct}

Example, when men want someone to close the door they will ay it directly "close the door!".

2. Judgement Adjectives

Example in conevrsation they will say "his performance is poor".

3. Brief Sentence

Exmple they will say "I want this. Not that. Right now!"

4. Self-references

Example "I'm in agreement with that"

5. Slang/ joke

Male in their communication use more slang words.

6. Politeness

Example the word "please or "thank you".

Lakoff (1975) states several linguistic characteristics used by women :

a. Color words

Example red, purple, blue, etc., but they divide the colors into smaller groups, for example beige (a pale creamy brown color)

b. Empty adjectives

Lakoff mentions that there are adjectives that have a tendency to be used Such as gorgeous, fabulous, lovely, charming, divine, adorable, and so on

c. Question intonation/intonational pattern

Example : "it's too cold here, can you close the door, please?"

d. Hedge

Some experts refer to the term hedge with several terms, for example stance marker (Atkinson, 1999). xample well, you know, kinda, sort of, like, I guess, I think, seems like, kind of etc.

e. Intensifier

The word so, very, totally is also an example of intensifier.

f. Super polite form / Politeness

Example "Do excuse me, but I really appreciate it if you could take a little time to help me". g. Hypercorrect grammar

Example "I would he very appreciate could show me the way"

h. Tag guestions

Example "John is here, isn't he?"

i. Avoidance of strong swear words

Example : oh my goodness, my goodness , oh dear, my dear, and so on.

j. Emphatic stress

For example, it was a brilliant performance.

\section{Narrative}

The areas of finding the linguistic characteristic is narrative writing by the students. Kilborn (1997) describe that narrative approach, more than any other, offers writers a chance to think and write about themselves. Narrative is introduced to amuse, enterain and to deal with actual or vicarious experiences in different ways. It deals with problematica events which lead to crisis or turning point of some kind which is turn finds a resolution.

Every human has experience in their memories which are worthy of sharing with readers. The purpose of narrative is to amuse, entertain, and instruct via reflection on experiences ( John: 2002).

Pardiyono (2007:94) he states that Narrative text is the type of text which is very appropriate to recount past activities or events, which high light the problematic experience and resolution with the intention to amuse and often intended to give moral lessons to the reader.

Knapp and Watkins (2005:220-221) stated that narrative has social role as a medium for entertainment and changing social opinions and attitudes. When reading Narrative Text from novel or short story, people tend to get the jollity. It means the aim of reading Narrative Text is to entertain their mind.

Narrative may also seek to teach or inform, to embody the writer's reflections on experience, and to nourish the reader's imagination (Derwwianka: 2004). To make a good narrative writing some conventions are also made as in Kilhorn (1997):

1. Narratives are generally written in the first person that is, using "" However, third person ("he," "she," or "it") can also be used.

2. Narratives rely on cencrete, sensory details to convey their point. These details should create a unified, forceful effeet, a dominant impression

3. Narratives, as stories, should include these story conventions: a plot, including setting and characters; a climax; and an ending. In order to make clear about narrative here is a simple example or narrative writing. 


\section{Types of Narrative Text}

Keraf (2010: 136-137) divides the narrative essay into two types :

\section{Expository Narrative}

Expository narrative is a narrative that aims to arouse mind of the reader to know what is told. By their nature the expository narrative is divided into two types :

a) Generalized Exposition Narrative

This narrative conveys something general, which can be done by anyone, and can also done repeatedly. For example, a nararif discourse that tells "How to make bread, how someone makes and prepares friedrice"

\section{b) Specific Expository Narrative}

This narrative tries to tell a typical event, which only happens once. A typical event is an event that cannot be repeated, because it is an experience or event at a certain time. For example the experience of someone who first entered a college, experience someone who first visited the ocean (Keraf, 2007: 137).

\section{Suggestive Narrative}

Suggestive narrative is a narrative that aims to give meaning or events as an experience, not to expand knowledge of someone's information.

\section{METHOD}

The method used in this study was qualitative method using document analysis technique. The subject of this study was linguistic characteristic of Narrative texts derived from Narrative text written by male and female students for Collage students in Sekolah Tinggi Jam'iyah Mahmudiyah Tanjung Pura. The focus of the study is on analyzing the sentences of Narrative texts. From each writing text that were analyzed to identify their criteria in term linguistic features

\section{FINDING AND DISCUSSION}

Male and female use language with different linguistic characteristic. Linguistic Characteristic of Narrative text Written by Male and Female Student :

1. Male's use Both Direct and Declaration with Interrogative Intination

So smoking should be prohibited especially for student

2. Male use both judgment adjective and taq question

Believe me it is better to better to avoid the damage of smoking for us as a young generation right.

3. Female use both Declaration with interrogation intonation
Are we new capable of showing emphaty for those who are still marginalized.

4. Female use both Taq Question Judgement adjective It may be hard but iam sure its only temporary right

There are no consistent characteristics of the language used by male and female student. the reason causing ones language for being more direct or less direct are ethnicity and personality traits.

\section{ACKNOWLEDGMENT}

R. B. G. thanks goes to her two advisors, Prof. Dr. Zainuddin, M. Hum her first advisor and Dr. Anni Holila, M.Hum as her second advisor for their all guidance, assistant, encouragement and valuable suggestions through the completion of this thesis.

\section{REFERENCES}

[1] Austin, J.L. 1962. How to Do Things with Words. Cambridge, MA: Harvard University Press..

[2] Bogdan, Robert and Biklen. 1982. Qualitative Research in Education : An Introduction to Theory and Method. Boston : Allyn and Bacon.

[3] Coates, J. (1986).Women, Men and Language. London: Longman.

[4] Gray, John. 2001. Men Are from Mars, Women Are from Venus, dialih bahasakan oleh T. Hermajaya. Jakarta: Gramedia.

[5] Gray, John. 1997. Mars and Venus Together Forever, dialih bahasakan oleh T. Hermajaya. Jakarta: Gramedia 